INTERGENERATIONAL SUPPORT AND REPRODUCTION OF GENDER

INEQUALITIES: A CASE STUDY FROM WESTERN AND EASTERN GERMANY

\title{
Authors
}

1. Andreas Klärner, associate professor at:

University of Hamburg, Department of Social Economics, Welckerstr. 8, D-20354 Hamburg, Germany

E-Mail: andreas.klaerner@,wiso.uni-hamburg.de

and

assistant professor at:

University of Rostock, Institute for Sociology and Demography, Ulmenstrasse 69, D-

18057 Rostock, Germany

E-Mail: andreas.klaerner@uni-rostock.de

2. Sylvia Keim, assistant professor at:

University of Rostock, Institute for Sociology and Demography, Ulmenstrasse 69, D18057 Rostock, Germany

E-Mail: sylvia.keim@uni-rostock.de

Funding: The research project "Social Influences on Family Formation and Fertility in Northern Germany", which generated the data used in this study, was subsidized by the Max Planck Institute for Demographic Research (MPIDF, Rostock) and executed by the Independent Research Group "Culture of Reproduction" at the MPIDF under the direction of Laura Bernardi.

Acknowledgments: We thank Angelika Tölke, Heike Trappe, and Peter A. Berger for useful comments on a first draft of this paper. We acknowledge Robert Schulz for language editing.

Word count:8693 words including figures and tables 


\title{
Andreas Klärner, Sylvia Keim
}

\section{INTERGENERATIONAL SUPPORT AND REPRODUCTION OF GENDER INEQUALITIES: A CASE STUDY FROM WESTERN AND EASTERN GERMANY}

\section{February 2016}

\begin{abstract}
Social support is often described as an exclusively positively acting factor. Its absence is said to mean negative consequences for individuals. This article shows that the supply and dependence of intergenerational social support can have negative consequences and pertains to persisting unequal gender roles and a gendered division of labor in relationships. Based on qualitative interviews, conducted in eastern and western Germany, with young adults (28-30 years old) and their parents, we hypothesize, that the bigger supply of intergenerational support of grandparents for their children and grandchildren and an alleged dependence on these transfers is especially responsible for impeding the modernization of traditional role models assigning women to the role as a mother and housewife. However, less availability and dependence on this kind of social support in eastern Germany, contribute to a more flexible form of role allocation in a relationship.
\end{abstract}

\section{Keywords}

gender roles

intergenerational relations

social support

gendered division of labor

male breadwinner model 


\section{INTRODUCTION}

Regarding studies of family and gender sociology, Germany is a special case. Its division after WWII induced the establishment of two different social and economic systems. The territory of eastern Germany was the sovereign, socialist state of the German Democratic Republic (GDR), the western German parts formed the sovereign democratic state of the Federal Republic of Germany (FRG), which implemented market economy. After the collapse of the Communist states in 1989/90 the existing political and economic structure of the FRG was superimposed on the territory of the GDR. This is important for studying gender relationships because the FRG and the GDR were different and contrary concerning family regimes, gender relations and state policies towards marriage and fertility (PfauEffinger and Geissler 2002; Salles 2006). Even today social science research finds remarkable differences between both regions (Huinink, Kreyenfeld and Trappe 2012; Krause and Ostner 2010), e.g. women from eastern Germany are much younger at their first childbirth, childlessness is less common for them, being unmarried and single mothers are more common (Konietzka and Kreyenfeld 2010). Also differences in the gender-specific division of labor in families are still obvious, but whether underlying gender roles differences have persisted or even intensified after the reunification - or whether equalization between East and West is happening, remains disputed (Kahlert 2010).

Explanations for persisting and changing conceptions of gender roles and the division of labor in relationships in eastern and western Germany mostly involve basic political conditions, changes to the labor market and different cultural concepts or socialization experiences. Our article discusses a further factor, which we feel has not been considered sufficiently: the different structure, availability and claiming of intergenerational support. Accordingly, the organization of intergenerational relationships of young adults in their 
reproductive age and how these relationships affect their behavioral roles and partnership arrangements are of our particular interest. We assume, that the bigger supply of intergenerational support of grandparents for their children and grandchildren and an alleged dependence on these transfers in western Germany is especially responsible for the transmission of traditional gender roles. Qualitative interviews with young adults and their parents, which were conducted 2004/5, constitute the basis of our investigation.

Next we introduce the different family models in eastern and western Germany and subsequently examine explanatory approaches concerning the emergence and development of these models. Then we explain the theoretical concept of intergenerational exchange processes, identify different types of social support and eventually pose our research question regarding the connection between intergenerational support and reproduction of gender inequalities. Our data and methods are introduced in the empirical section. Subsequently we present summarized results and two case studies from eastern and western Germany.

\section{Family Models And Gender Relations In Western And Eastern Germany}

Concerning family models, the GDR and the FRG exhibited until the 1980s a development which was very homogeneous within the respective state, but in comparison very different.

The quasi-standardized family model in former West Germany represented the male breadwinner and the housewife who, after marriage or giving birth to the first child, managed the household and the children and oftentimes did not return to her profession. This model was and is subsidized by the state e.g. by tax benefits (Pfau-Effinger and Smidt 2011). The conception regarding gender roles and actual role behavior changed slowly. Indeed, 
during the cultural revolution of 1968 and coinciding with the emergence of feminist movement in the 1970s/80s ("emancipation from below), "traditional” role patterns were questioned. Growing educational participation of women regarding education, a recent shortage of skilled labor and men increasingly wanting an "active fatherhood" (Werneck, Beham and Palz 2006) led to higher employment of mothers and fathers engaging more in tasks related to care and upbringing (Holst and Schupp 2001; Trappe and Sørensen 2006). Public childcare was and is severely expanding and it is imaginable that sooner or later more gainfully employed mothers may change traditional role models. It is evident at least, in time comparison (1988-2000), that western Germans are progressively attuned against a housewife existence and for part-time employment of mothers of children who go to kindergarten or school (Heß 2010). However, the traditional male breadwinner model proved to be very stable in practice and gender differences continue to persist. Although childless partners are both employed nowadays, the transition to parenthood coincides with a retraditionalization of gender relations: mothers take care for the child, mostly work part-time and only when their children are older, while fathers remain employed full-time and perform their care and upbringing activities in their leisure (Fthenakis, Kalicki and Peitz 2002; Rüling 2007).

In the GDR regulatory actions successfully forced a different family model ("emancipation from above"). Standard was the two-income family, mothers interrupted employment only shortly, part-time work was less common and mothers seeking to reduce working hours experienced more pressure to justify (Falk and Schaeper 2001; Trappe 1995). Accordingly, in 1989 employment of women amounted to 82 percent in the GDR (mostly full-time), but only 56 percent in the FRG (mainly part-time) (Hülser 1996). Though high female labor participation depicts an important aspect of gender-mainstreaming, gender roles still were 
unequal in the GDR and women bore the main responsibility for family and household in addition to gainful employment (Kolinsky 2003; Schmitt and Trappe 2010).

Empirical results concerning changed gender roles and family models in eastern Germany since the reunification are inconclusive. In 1994 the non-traditional gender role ideology was most prevalent in eastern Germany based on internationally comparative data (Yodanis 2005). Several current studies find evidence for both sexes still rejecting the western German breadwinner model, and emphasizing the necessity and desire for reconciling work life and motherhood (Author YEAR; Boehnke 2009; Heß 2010; Kreyenfeld and Geisler 2006; Rudd 2000). The share of households with both parents (youngest child younger than 3 ) working full-time was in 2012 almost four times higher in eastern Germany (18.4 percent) compared to western Germany (4.8 percent; cf. Statistisches Bundesamt 2013a). Comparative studies point to consistent East-West disparities, e.g. attitudes towards gainful employment of mothers, which clearly enjoys a more positive evaluation in eastern Germany (Wenzel 2010). Eastern German men also tend to engage more frequently in childcare and the household (Heß 2010). However, other studies suggest a convergence of eastern German couples to the western German additional income model, a "West-Germanization" respectively (Rosenfeld, Trappe and Gornick 2004; Thelen and Baerwolf 2008).

\section{Explanations For Persisting And Changing Gender Roles}

Literature oftentimes attributes persisting differing conceptions about gender roles and family models to different, durable, cultural overall concepts (Pfau-Effinger and Geissler 2002): Similar to GDR times gainfully employed mothers are natural in eastern Germany and positively valued (Huinink and Konietzka 2003). Contrarily, in western Germany predominates quite a special "myth" of the German mother (Vinken 2001): Motherly childcare is valued ideal, (full-time) employment of mothers is valued negatively and 
considered harmful to the child's development (Heß 2010). The persistency of the western German family model can still be ascribed to consequent government aid of this model and difficulties practicing other models (e.g. income splitting, insufficient public childcare facilities). The still prevalent East-West disparities, especially concerning the supply of childcare facilities, which was only partially abolished in post-turnaround eastern Germany, may explain another cause for the permanently differing family models and gender roles. The supply of nationwide full-day childcare enabled many eastern German mothers to reconcile homemaking with full-time employment. However, in western Germany access to full-day childcare is less common, especially for children under 3 years. In 201427.4 percent of western German children younger than 3, compared to 54 percent in eastern Germany, attended a childcare facility or daycare (Statistisches Bundesamt 2014). In eastern Germany comparatively many children younger than 3 enjoy full-day childcare (i.e. 37.3 percent; 10.4 percent in western Germany, cf. Statistisches Bundesamt 2013b). It is assumable that these conflicting care systems cause persisting differing gender arrangements in eastern and western Germany.

However, observed changes in eastern Germany suggest in some areas an approximation to the modernized western German family model (Heß 2010; Thelen and Baerwolf 2008). This does not necessarily indicate a change of attitudes, but may also be attributed to the worsening of employment opportunities for eastern German mothers (Giesecke and Verwiebe 2010).

Western Germany also displays an interesting change which could affect family models and gender roles. Recently the number of childcare facilities, especially for under three-yearolds, has increased drastically and this extension is supposed to continue. Parents' initiatives have also inspired the foundation of facilities offering more flexible childcare. Regarding the 
change in federal family policy Ilona Ostner (2006) speaks about an approximation of the West to the East. This could set the course for an increase of two-income parents and a change towards more egalitarian gender roles in western Germany (Heß 2010).

Changes on the labor market offer another explanation for increased employment of mothers in western Germany. The disappearance of "normal" employment and increase of precarious occupations is impeding men to solely fulfill the role as breadwinner. Thus traditional gender roles and family models are also unhinged due to the plain economic necessity of women participating in gainful employment (Kahlert 2007).

Additionally to these explanations we would like to examine persistence and processes of change from a perspective of an, in our opinion, hitherto neglected structural category: whether and in which way gender roles and family models are negotiated, passed on or modernized via intergenerational interactions within the family. Our thoughts base on a relational perspective of human action:

"Actors do not behave or decide as atoms outside a social context, nor do they adhere slavishly to a script written for them by the particular intersection of social categories that they happen to occupy. Their attempts at purposive action are instead embedded in concrete, ongoing systems of social relations." (Granovetter 1985: 487)

Intergenerational interactions are an important part of everyday interactions and family members "significant others". Additionally, intergenerational relationships are perceived increasingly as socially significant, since the prolonging of average lifetime has enabled parents to live on average more than 50 years of their child's life (Lauterbach 1995) and grandparents on average more than 20 years of their grandchild's life (Lauterbach and Klein 
1997). In this time occur many intergenerational interactions and exchange processes, whose structure we examine in the following.

\section{Intergenerational Exchange Processes And Family Models}

Research has registered increasing interest in intergenerational exchange and transfer of support. Hereby the focus is on support grown up children offer their parents. At the moment, the other direction of support from grandparents to their offspring plays a subordinate role in research (Brandt 2009).

Yet, we argue both directions of transfers are important: a particular structural feature of family relationships is the simultaneous intra- and intergenerationality and the constant (unequal) exchange of social and material goods. These exchange relations (Figure 1) occur horizontally within one generation, e.g. exchange of love between parents (G2), quarrels between siblings (G3), competition between maternal and paternal grandparents (G1m, G1v), but also vertically, e.g. exchange of caring support between parental generation (G2) and care-dependant grandparents (G1). 
Figure 1: Structure of intergenerational exchange processes

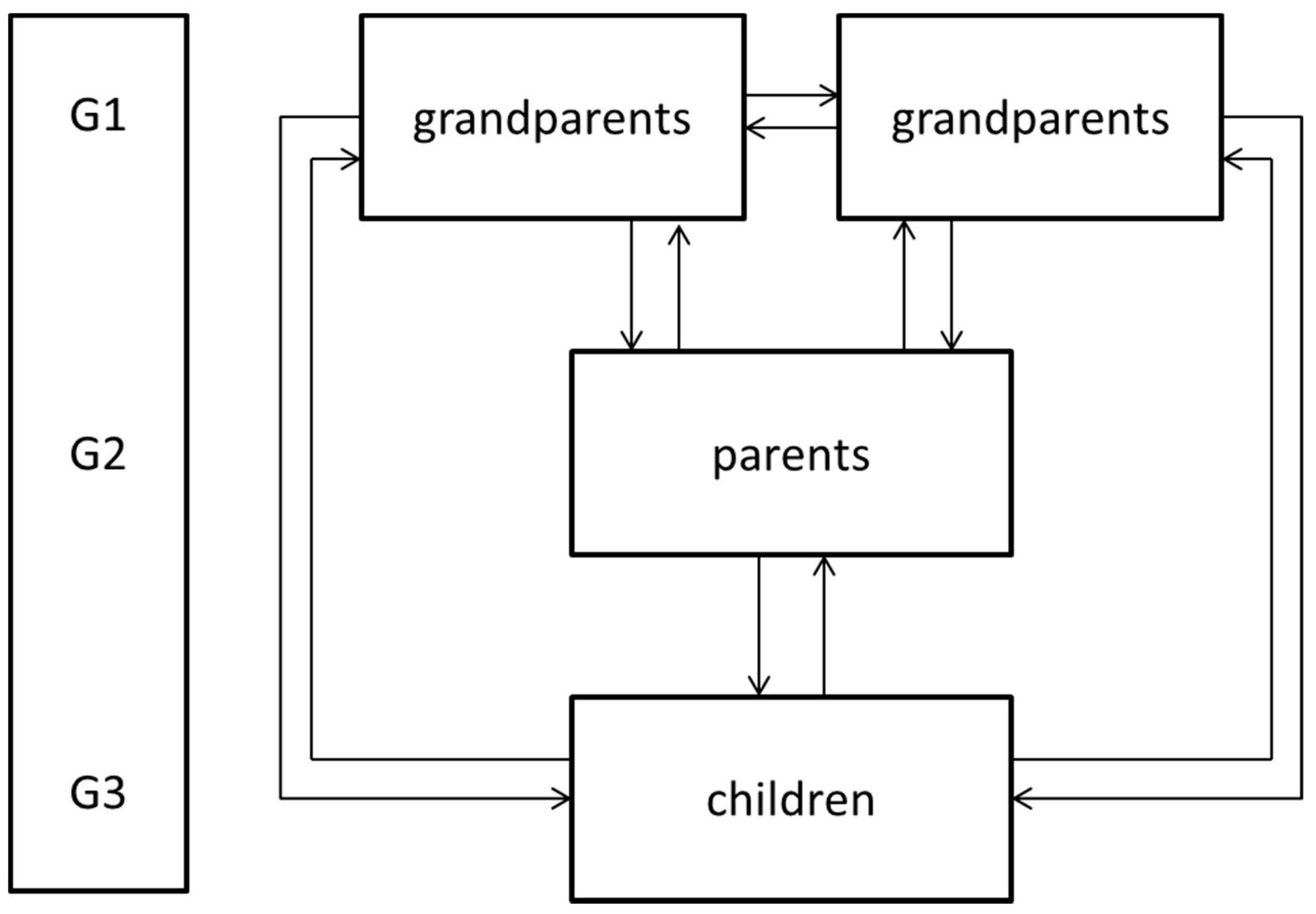

Source: own illustration basing on Kohli and Künemund 2001: 165 ff.

In the following we will elaborate the East-West differences regarding intergenerational exchange processes. We start by distinguishing four types of intergenerational support: material, practical, cognitive and emotional (cf. Diewald 1991 and Table 1). 
Table 1: Types of social support

\begin{tabular}{|l|l|l|l|}
\hline Material & Practical & Cognitive & Emotional \\
$\begin{array}{c}\text { nonrecurring money } \\
\text { transfers }\end{array}$ & $\Rightarrow$ (child)care & $\Rightarrow$ Orientation and & $\Rightarrow$ Security, love, \\
other household & $\Rightarrow$ Sense of & affection \\
Noncash benefits & duties & belonging & Comfort, \\
$\Rightarrow$ Bank guarantee & $\Rightarrow$ Repair work etc. & $\Rightarrow$ Appreciation & $\Rightarrow$ Confidence in \\
$\Rightarrow$ Endowments & $\Rightarrow$ Guidance & & support, \\
$\Rightarrow$ Asset transfers & & & reliability \\
$\Rightarrow$ Inheritances & & & $\Rightarrow$ Companionability \\
\hline
\end{tabular}

Source: own illustration based on Diewald 1991.

Material support occurs mainly through money transfers of different types (endowment, credit, bank guarantee, etc.). According to DEAS (Deutscher Alterssurvey) data of 200817 percent of the 70 to 85 -year-olds provide material transfers to at least one of their children, 18 percent provide direct transfers to their grandchildren. Concerning the 55 to 69 -year-olds more than 25 percent support their children and about 12 percent their grandchildren (Mahne and Motel-Klingebiel 2010: 203). Comparing eastern and western Germany there are considerable differences: In 200229 percent of western Germans older than 40 supported their children with money transfers and noncash benefits, in eastern Germany this applied to only 24 percent, in 2007 this applied to 27 percent in western Germany and 22 percent in eastern Germany (Motel-Klingebiel, Wurm and Tesch-Römer 2010). Inheritances and endowments occur more often and involve higher amounts in western Germany (Kohli et. al 2001; Szydlik 2004). 
Practical support is manifold; we are most importantly concerned with childcare. According to DEAS data of 200855 to 69 year old grandparents, especially grandmothers, care for their grandchildren most frequently (Mahne and Motel-Klingebiel 2010: 206). In 199636 percent of eastern Germans older than 40, compared to 33 percent in western Germany, provided this type of practical support. This is explained by a significantly higher share of people with children and grandchildren in eastern Germany and does not hint to a necessity or a higher degree of implicitness of this support in eastern Germany (Kohli and Künemund 2001). Higher unemployment or early retirement of eastern German grandparents increases opportunities to care for grandchildren (Uhlendorff 2003; Thelen 2005). However, these ratios reversed: in 2002 and 2008 only 22 percent, 17 percent respectively, of the eastern Germans older than 40 provided childcare as practical support, whereas western Germans offered 30 percent, 27 percent respectively (Mahne and Motel-Klingebiel 2010: 207).

Cognitive support refers to the mediation of states of consciousness (Diewald 1991). Intergenerational interactions communicate, pass on and modify cultural concepts, standards and values. As stated above, some studies indicate a strong intergenerational correspondence regarding attitude and behavior concerning gender roles, possibly underlying an intergenerational transmission of standards and values. Other studies detect changing family models and gender roles, indicating obsolete orientational knowledge of the older generation in some areas, where hence the younger generation probably communicates orientational knowledge to the elders. Concerning East-West comparison two things seem conceivable: a reproduction of cultural concepts in western Germany due to relatively stable societal circumstances, observable via the male breadwinner model; while in eastern Germany attitudes and behavior from GDR times (many employed mothers, compatibility of family and career) became obsolete, disabling parents to offer their children orientational knowledge. Considering societal change in western Germany, it is also thinkable, that 
orientational knowledge of western German parents (standard employment) is viewed as inadequate causing uncertainty, regarding starting and organizing a family, with the younger generation (Author YEAR). Empirical studies, concerned with whether and how family models and gender roles are passed on via cognitive support, are rare.

Emotional support depicts an important personal resource. Compared to their western German counterpart young eastern German adults specified slightly more often a closer relationship to their parents and that they help with personal problems (Masche 2000). According to Masche a higher family orientation as a GDR relic is not necessarily the cause for stronger generational bonds, but the higher concentration of problems (e.g. unemployment) in eastern Germany compared to western Germany.

Regarding family models and gender roles our knowledge about precise transmissions between generations and East-West differences is limited and results are contradictory. Further, there is little knowledge, regarding the role of (expected) support, of how these transfers affect transmission or persistency and transformation of gender roles and family models. With this article we seek to examine: 1.) Which different types of gender role models, family models and arrangements of division of labor in relationships exist in eastern and western Germany? 2.) Which kind of support do young adults expect, receive respectively, from their parents, especially when starting a family? Of complementary interest: Which kinds of support are provided by grandparents to their children? Which support would they offer when their children start a family? 3.) How do these expected supports affect transmission or persistency and transformation of gender roles and family models? 


\section{DATA AND METHODS}

To answer these questions we revert to qualitative interviews with young adults from eastern and western Germany, which were conducted in 2004/5 as part of a bigger research project

(cf. Bernardi, Keim, Lippe 2007; Bernardi, Keim, Klärner 2014). This project examined how the social network of young adults influences the decision for parenthood and the precise arrangement of cohabitation in partnerships and families. Altogether 118 interviews were conducted, with: (1) the main interviewee (ego), young adults with intermediate and higher educational qualification, and if possible (2) their partners, (3) parents and (4) friends (alteri). The majority of our interviewees were childless at the time of the interview. Some had one child, a few two children. We conducted the interviews in an eastern German and a western German town: Rostock and Lübeck. Apart from belonging to different societal systems during the 40 years of the division of Germany both towns are similar in many ways: they are Hanseatic cities located in the protestant north of Germany and inhabit about 200,000 people. Both towns experience high unemployment, though it was a lot higher in Rostock when the interviews took place (13.8 percent in Lübeck compared to 7.6percent in western Germany; 18.2 percent in Rostock compared to 17.7 percent in eastern Germany).

The problem-centered interviews (Witzel and Reiter 2012) with ego focused on life hitherto and future plans, particularly regarding partnership, imaginations concerning starting a family and intergenerational and other relationships. The interviews with ego's parents dealt with their experiences starting a family, imaginations and wishes regarding their children's life, the relationship to their children and interactions and exchange processes.

Interviews lasted 60 to 120 minutes and contained narrative passages about individual attitudes concerning gender roles and labor division in a relationship, actually practiced labor division, imaginations regarding the labor division upon arriving parenthood, attitude and 
imagination of childcare and the role of grandparents. The interviews were transcribed verbatim and analyzed according to the method of thematic coding (Flick 2014).

For this article we have analyzed all available interviews concerning presented family models and gender arrangements as well as received and expected support. In order to examine how support contributes to persistency or change of family models and gender roles, we have analyzed the 25 available parent-child dyads from both towns comparatively.

\section{RESULTS}

Analyzing the ego interviews there are important differences between eastern and western Germany, regarding attitudes concerning family formation, , gender roles, childcare and practical arrangements concerning family life and work (see Table 2). 
Table 2: Gender role models Lübeck and Rostock sample

\begin{tabular}{|l|l|}
\hline \multicolumn{1}{|c|}{ Lübeck } & \multicolumn{1}{|c|}{ Rostock } \\
no children are planned, existent & Mostly egalitarian gender roles; \\
respectively, in the partnership; & between partners \\
employment and housework are allocated & \\
between partners & \\
\hline $\begin{array}{l}\text { Adoption of the (modernized) male } \\
\text { breadwinner model once there are children; } \\
\text { mother adopts role of a housewife, part- }\end{array}$ & mothers is natural \\
time employee respectively & \\
\hline $\begin{array}{l}\text { Childcare is assigned to the mother and } \\
\text { oftentimes also grandparents; public } \\
\text { childcare for children up to three years is }\end{array}$ & institutions (kindergarten etc.) and parents, \\
valued negatively & \\
\hline
\end{tabular}

Source: own illustration

Interviewees in Lübeck favor a gender-neutral allocation of tasks in the partnership and household. Male and female interviewees share the view that women are entitled to higher education and full-time employment, but only as long as there are no children in a partnership. If children are planned or already born almost all interviewees from Lübeck radically breach with favoring (and practicing) gender-neutral arrangements and revert to the male breadwinner model which was practiced and exemplified by their parents. A few interviewees problematize this model, because it penalizes women in advancing in occupational life, but are unable to establish a different labor division "in their special case". 
The rather depreciative characterization of fulltime institutional childcare, especially for children younger than three, is conspicuous.

I'm not a mother who gives her child to a nanny, because I have to work. I would only do this if I needed to financially. (...) But I actually think it's terrible for the children. (...) Being close to the mother, I think, that's very important for children. (L03ef0, female, living apart together, childless)

Many female interviewees who enjoy and want to keep their current full-time employment declare uncertainty about when and whether they want children or have already decided to remain childless, because they rule out compatibility of career and family:

It's not like I'm strictly against having children, but I say, I don't need them (...) The point is, I don't want to give up my life... [Having children] is a full-time job and I would be financially dependent on my husband, I couldn't work the first three years, because I wouldn't know where to keep the child. (L58ef, female, single, childless)

The childless interviewees from Rostock show no distinct awareness of problems concerning compatibility of career and family or division of labor in a partnership - the actual practiced division of labor is not necessarily completely egalitarian though. However, both partners show an egalitarian orientation towards full-time employment. Unlike with western German interviewees, this conception remains unchanged with children in the relationship. Full-time employment of women and mothers is natural, housewives are a deviation:

We had one in primary school whose mother was a housewife. And we always asked him, what does your mother do, what does she do the whole 
day? That was a really exotic creature for us, a housewife. (R02ef0, female, single, childless)

The compatibility of family and career is unburdened by conveniently available full-time childcare facilities, which are not considered problematic for the child. Interviewees from Rostock, in contrast to Lübeck, do not regularly expect help from grandparents concerning childcare.

Looking closer at the different support expectations and transfers, we find that most interviewees from both towns report (very) good relationships to parents/parents-in-law and state frequent contact. Family conflicts, possibly leading to severance, occur sparsely. Our analysis focuses on transfers from parents (G1) to their children (G2). We considered interviewees who already have children (G3) and who are childless.

The interviewees from both towns have different expectations concerning support (see Table 3). We observed mostly a congruence between expectations of young adults to their parents regarding support and willingness and capability of the parents to provide support. Individual interviewees, whose parents we could not interview, complain about a poor relationship to their parents and wish for more support. 
Table 3: Expected and received support in Lübeck and Rostock sample

\begin{tabular}{|c|c|c|}
\hline & Lübeck & Rostock \\
\hline Material & $\begin{array}{l}\text { Frequent or bigger financial } \\
\text { transfers, provision of housing, } \\
\text { Taking over bigger acquisitions for } \\
\text { the grandchild }\end{array}$ & Irregular role \\
\hline Practical & Frequent childcare & Irregular childcare, in emergencies \\
\hline Emotional & $\begin{array}{l}\text { Security, assistance, trust and } \\
\text { reliability }\end{array}$ & $\begin{array}{l}\text { Security, assistance, trust and } \\
\text { reliability }\end{array}$ \\
\hline Cognitive & $\begin{array}{l}\text { Stronger orientation; motivation: } \\
\text { parenthood as a calculated risk }\end{array}$ & $\begin{array}{l}\text { Limited orientation; motivation: } \\
\text { parenthood is natural }\end{array}$ \\
\hline
\end{tabular}

Source: own illustration

Interviewees from Lübeck and Rostock experience identical emotional support from their parents: They feel safe and trust their parents as helpers in need and reliable interactional partners. The other types of support indicate important differences. Material support is very important for interviewees from Lübeck: parents support their children financially (frequently or selectively concerning bigger acquisitions), they provide housing (condominium, or flat in the parents' house), they also take over bigger acquisitions for the grandchild and start savings plans. Most interviewees from Lübeck emphasize that their parents grant them financial security and thus ease starting a family. Even in difficult 
situations (e.g. when unintentionally getting pregnant during education) they can rely on this support.

Contrary to this material support plays an irregular role with the interviewees from Rostock. They benefit less from parental support. Access to material support is also unimportant when starting a family and thus not an issue.

There are also important differences concerning the availability of practical support. The (grand)parents (especially the grandmother) of the parents among the interviewees from Lübeck regularly help with childcare on certain days or at least quite often to allow a parttime employment of the young mothers:

Sure my parents-in-law and my parents offered help already during my wife's pregnancy. (...) and now my wife works eight days a month, every second weekend Friday to Monday. Saturday, Sunday I am there anyways. And Fridays he is with her parents and Sundays, Mondays with my parents, works well. (L53em1, male interviewee married, 1 child; mother: housewife, father: employee; mother-in-law: part-time employed, father-in-law: early-retired).

Many childless Lübeck interviewees thinking about parenthood expect their potential grandparents to provide this kind of support once grandchildren are there.

However, inability of grandparents to care for their grandchildren due to geographical distance, full-time employment, old age, sickness or poor contact is mostly viewed as a deficit leaving the Lübeck interviewees unsure about how to organize childcare and occupational comeback of the mother:

My parents are not there, her parents are not there for us, ... they are simply not there, to create time for us (...) also to create leeway for my wife. So that 
she says, she gets other tasks apart from only seeing (the son). (L59em1, male, married, 1 child, broken ties to parents and parents-in-law due to dispute)

The Rostock interviewees assume that grandparents' support alone is insufficient to enable an employment for the mother. They do not expect regular support; oftentimes they do not receive it since both grandparents work full-time or live far away. Even if a grandparent is early-retired or unemployed, regular help with childcare is not expected. However, parents can rely on their parents' help in emergencies if those live nearby and the relationship to them is good.

Cognitive support for instance refers to children orienting their own behavior by the attitudes, behavior, values and experiences of their parents. This is particularly apparent with the western German interviewees. They explicitly justify their positive evaluation of the male breadwinner model and rejection of both parents working full-time with experiences in their family of origin:

I think it's good if someone stayed with the child, I can say this from experience, because my mother didn't work, I also cannot imagine how it is if both parents work. (L05em, male, single, childless; mother: housewife, father: public officer)

Concerning this issue and the perception of children as "calculated risk", the attitudes and behavior of the interviewed young adults and their parents coincide strongly. Children are considered potentially threatening to material wealth if there was not a certain standard of material security established beforehand. Before starting a family, parents (G1) from Lübeck expect from their children first to finish vocational training, enter into employment, for the husband to find a reliable employment and earn a certain material basis. This attitude is 
shared by the children (G2), who thus mostly have specific ideas about how and when to start a family. Shared is also the ideal of a mother who above all cares for their children and a rather negative evaluation of full-time employed "career-obsessed" mothers.

Conspicuously, interviewees from Lübeck hardly challenge "traditional" gender roles and partnership arrangements.

Only some interviewees from Lübeck refer to societal change (e.g. educational expansion, pluralism of lifestyles and family structures, increase of instable employment) and resulting differences to their parents. The Rostock interviewees and their parents show congruence concerning the attitude that parenthood is natural and can be arranged flexibly. Both also view employment of mothers positively. Partially, the own parents are also seen as role models:

My parents both have their career, have made arrangements. And they have divided the work. That's my requirement to a relationship...Well, sure, my mother did the ironing and my father repaired the bikes, but my father also cleaned and he didn't dodge any work, ...that's quite emancipated. And I imagine it like this, too. (R02ef0, female, childless)

Oftentimes the issue is raised that things common in the GDR are not transferrable to today's circumstances:

It's not like people "take their time", they are forced to get children later. At age 26 one was latest parturient in the GDR. And today it's easy, one has to finish vocational training first, before one can take the time for children. Then they say, especially with any academic higher degrees, I have to make my career first, get used to working first, it's the women after all who get the children and to get them back to work. They want to establish a basis first. 
Insofar "they don't take their time" - they are forced to organize time differently. (R19ef1, female, cohabiting, 1 child)

This quote implies that the eastern German interviewees also experience the necessity to consider a stronger sequencing of life events - first career, then children. However, speaking of "West-Germanization" here would be wrong. Neither intrinsic motivation nor the inner need for security - which apply to the western German interviewees - make such sequencing desirable. It is rather an externally imposed "enforcement" which makes an orientation towards occupational careers appear necessary, since otherwise mothers cannot realize fulltime employment, which is taken for granted. Hence, longer career breaks after giving birth or part-time employment do not indicate a voluntary approximation to a "western German lifestyle" or "western German family model", these rather respond to the difficult employment situation of mothers in eastern Germany.

Apart from emotional support our interviews exhibited important East-West differences concerning all other types. Material help and practical support regarding childcare are increasingly provided or expected by the western German interviewees. Cognitive support is received by interviewees from both towns, contents differ entirely though. In Lübeck children are ill-reputed by both generations as calculated risk and the male breadwinner model alongside the ideal of the caring mother is passed on. In Rostock parents pass on the naturalness of "having children", compatibility of family and work and flexibly managing both.

To examine how intergenerational relationships and support affect the conveying of gender roles, we have contrasted the narratives of female egos (G2) with the ones of their mothers (G1). Two case examples featuring young women from Lübeck and Rostock illustrate 
hereinafter typical East-West differences and intergenerational influences on gender roles and partnership arrangements.

\section{CASE STUDIES}

Both cases feature young women with each one child. The case illustration focuses primarily on narratives (from G2) concerning the decision for parenthood, labor division in the partnership and the how the parents influenced these processes. Additionally we have analyzed the narratives of the respective mother concentrating on statements concerning interactions with her daughter, her description and evaluation of her daughter's family model.

\section{Lübeck: Lisa And Lisbeth (L15)}

Lisa is 29 years old at the time of the interview, has a nine month old child and is on maternity leave. Concerning her lifestyle and thoughts she represents a typical case from Lübeck. She is married to a public officer older by four years, has a higher qualification and is just starting her civil service career. She maintains a good relationship to her parents and mother-in-law, who live in the same town, including close and frequent contact.

Lisbeth, Lisa's mother, is 55 years old, housewife, mother of two and also married to a public officer. After completing her vocational training and working shortly in her job she became pregnant at age 21 . Her husband was already 31 and public officer. As planned they married first and had the first child, Lisa's older sister then. Lisbeth has been a housewife until Lisa was three years old, then she worked part-time for 12 hours a week.

Lisa was a lot older than her mother at her first pregnancy, but she and her partner were in the same biographic phase: Lisa and partner got their first child after completing vocational training and achieving a reliable occupation. Their division of labor was mostly egalitarian 
before the child. Ever since Lisa is responsible for child and household and her husband acts as main breadwinner. Unlike her mother, Lisa seeks part-time employment once the child turns one. Full-time employment is out of question in the near future.

Lisbeth supports Lisa's attitude. It is important for her that mothers "are there for their children", but also that women earn their own living in emergencies (she particularly thinks of risk to divorce) and thus should learn a good profession and refrain from interrupting work for too long. Therefore she has offered regular support in childcare and they have arranged that she and Lisa's mother-in-law will share providing this support, once Lisa returns to work:

With Lisa, her mother-in-law and I want to share it, Lisa wants to return to work in May, twelve hours, then one day the one mother takes and another day the other mother, that's okay, nowadays without grandma and grandpa one can't get children anymore. (Lisbeth)

Thus Lisbeth clings to traditional gender roles, but also enables, due to her childcare commitment, a modernization of this family arrangement. Providing support is also connected to propagating attitudes and values. Lisbeth describes her mother image:

I favor, that mothers are there for their children, but they should also work, if possible not the whole day. As for me children come first before work. (Lisbeth)

Thanks to the social support via her parents, Lisa seemingly takes this combination of family and work for granted. She refuses extra-familial and institutional childcare, because the family provides "better" care and ought to be preferred, an attitude shared by many western German interviewees. She also senses certain social pressure and knows, 
If one chooses a nanny, the parents would feel offended. (Lisa)

Hence, the parents offering social help is also linked to expectations in return, specifically refraining from "giving away" the own child to "external care", as well as from working fulltime and havint to rely on all-day care.

\section{Rostock: Ronja And Renate (R11)}

Ronja is 29 years old and has a four year old child. She achieved a higher qualification and has a full-time, although temporary, employment. She is unmarried, but is in a partnership with the child's father. He also achieved a higher qualification and has a permanent full-time contract. Renate, Ronja's mother, is 54 years old, married, has two children and works fulltime in a well-paid ambitious job which corresponds to her university degree.

When speaking about organizing childcare Ronja's parents are not mentioned. Ronja and her husband take turns. The rather egalitarian role allocation has prevailed since childbirth. They practice the two-income model and trust public childcare facilities. Ronja says: "My son has gone to kindergarten since he turned one". They are independent from their parent's support and do not expect it.

There are remarkable similarities between Renate and Ronja concerning labor division in a partnership. Answering the interviewer's question if she could generally understand that highly educated people are fixed on their occupational career and voluntarily relinquish having children, Renate says she has "always worked (...), I have never stayed at home", she "did not take maternity leave", and still they shared the remaining time with the children. Accordingly, both her children did not suffer from her occupational life and she is pleased with how her children grew up and how they are living. This also applies when she had to travel in her job and was often absent at home - then her husband took over: "When I wasn't 
there, he was for the children. That's somewhere manageable, if one wants to". Renate's and her husband's parents were unable to help, because all four were working. The availability of public childcare facilities helped them a lot. Ronja and her partner have a similar arrangement. Both work and equally care for their child. Renate's influence on Ronja and her support is rather emotional and cognitive. Ronja adopted her quasi-natural attitude towards children from Renate, i.e. children are part of life. The cognitive orientation exceeds the propagation of functioning, inelastic behavioral patterns and role models. It is more flexible and manifests itself in a type of arranging ability:

Fortunately, [Ronja] completed her studies almost in the standard period, which was tough, but couldn't get her traineeship then, that takes long, before it's your turn. She said, then she gets her child in between, I thought that was great. I think we partially exemplified this, that it's not that difficult with a child. They have other problems than us, with security. Housing is not an issue, but work, career opportunities...but both are, my son-in-law, well they are not married, today it's also not that anymore... but they both got a job, and this without problems after studying. (Renate)

This reveals that Renate consciously tries to pass on the cognitive certainty to be able to actually overcome such difficulties and trust that this harms neither parents nor children.

\section{SUMMARY AND DISCUSSION}

Our interviewees from Rostock and Lübeck demonstrate important differences concerning personal preferences and actually practiced gender arrangements in a partnership. The western German interviewees do opine egalitarian attitudes concerning women participating 
in occupational life and labor division in partnerships, but in most cases only when there are no children, yet. Upon the birth of the first child the male breadwinner model, exemplified by the grandparents, is usually adopted. This model is partially modernized by acknowledging that women, mothers respectively, are needed to participate in gainful employment. Besides insufficient public childcare, the traditional ideal of a mother, which is internalized by our interviewees, disfavors full-time employment. Mothers are widely regarded as the nature's best guardian who fends for a good development of the child. Many women struggle to reconcile their wish for children and their mother image with their conceptions concerning professional life. They are unsure whether and when to get a child or relinquish having children in favor of practicing their profession.

An egalitarian partnership arrangement, where women return to full-time employment after getting a child, childcare is organized cooperatively and public institutions are trusted, is much more common and natural for the eastern German interviewees. Deviations from the two-income model are mainly caused by unemployment or vocational training and less by refusal or reservations regarding institutional childcare.

So, how do intergenerational relationships affect the passing on (and transition) of gender roles and partnership arrangements?

We demonstrated that western and eastern Germans usually maintain close relationships, which are characterized by frequent interactions and mutual support, to their parents and parents-in-law. However, differences concerning the attributed importance of and access to certain types of support were evident.

The western German interviewees benefit from more frequent and higher material transfers. Financial security is also an especially important precondition for starting a family (cf. also Author YEAR). Thus the interviewed young adults attach value to the opportunity of 
receiving material support from their parents. This also applies essentially to practical support in childcare. The grandparent's help is necessary because of insufficient public childcare possibilities and unwanted public childcare for little children or longer periods of time since external care is evaluated negatively. These close intergenerational relationships provide certain material and practical support (most likely from grandparents to parents), but also pass on or negotiate oriental knowledge. Concerning the importance of support related to childcare, the western German interviewees feel in a way dependent on their parent's help who also possess considerable power to sanction if their children act outside their expectations. The social trade-off simultaneously constitutes interdependency (Blau 1964), whereby the grandparents emphatically formulate certain role expectations to their children, especially their daughters who ought to take care of the children primarily. Since most grandparents strongly opine a male breadwinner model, a modernization is limited. Indeed, the two-income model including children is unimaginable for most of our western German interviewees or even offensively refused by both generations. However, even the interviewees in Lübeck have undergone change and both generations emphasize preference of a modernized breadwinner model where the mother works part-time. Especially parents of daughters are aware that partnerships and also occupations lack stability compared to their times. Thus they often urge their daughter to learn a profession and return to their occupation part-time shortly after the birth. For this they offer support concerning childcare.

Contrary, the access to comparably small material and partially practical support does not prevent the eastern German interviewees from starting a family: they do not necessarily require a high degree of financial security. Regular childcare via the grandparents is also considered unnecessary, because most interviewees perceive sufficient public care facilities and adequate care. In comparison to the western German interviewees they do not experience such strong dependency on the grandparents. Hence, the eastern German 
interviewees enjoy more leeway following gender models, partnership arrangement respectively, different from their parents. Originally we assumed that, due to the societal turnaround, orientational knowledge of the grandparents in eastern Germany had become obsolete. However, the interviews in Rostock showed that the younger generation shares many beliefs and values with their parents: the two-income model with children and flexibly managing family and professional life is still natural, coping with adverse circumstances is passed on from generation to generation. Thus it is important that changed circumstances do not conclude outdated orientational knowledge. The type of passed on orientational knowledge ought to be subject to research. We claim the eastern German interviewees are better prepared for the current situation in the unified Germany - e.g. difficult employment situation, problems arranging family and career - because both partners show more flexibility, pragmatism and willingness to work full-time. Part-time employment or nonworking mothers are possible, an arrangement which is less opposed by grandparents in eastern Germany than the two-income model in western Germany. For this reason the eastern German interviewees are also less likely to respond to the mentioned difficulties with postponing the decision for parenthood or relinquish having children. Although the eastern Germans hardly raise issues concerning gender equality, one must record that in practice women still contribute more to chores and childcare.

Our data does not suffice to answer the question concerning change or persistency and reproduction of unequal gender roles and partnership arrangements clearly, least of all representatively for eastern and western Germany. The investigation of people with a low educational level would be especially interesting, as our sample lacked those. Many factors caused the still existing differences between eastern and western Germany, which subsequently enforce the reproduction of gender inequalities and traditional family models: the fiscal system, labor market structures, personal preferences, cultural aspects etc. 
However, the availability, (alleged) dependency and actual exchange of social support and orientational knowledge between grandparents and parents also play an important role. We hereby claim the mentioning of this insufficiently considered factor.

To formulate a concluding thesis: Receiving cognitive orientation from the grandparents causes the passing on of traditional role models, which the younger parent generation orients itself by. This intensifies if there are dependencies concerning material and/or practical support. However, the passed on models are bound to change according to current societal circumstances. Parents and their children in western Germany assume that the pure housewife model has become impractical and employment of the mother necessary and thus cause a modernization of the male breadwinner model in practice. However, the traditional attitude, that mothers above all have to take care of their children, persists. Either way an occupation is secondary. This opposes the implementation of the two-income model and an egalitarian labor division in partnerships. The availability and (alleged) dependency concerning grandparental material and practical support also provokes the western German interviewees to be emotionally dependent on them and their judgments thus limiting opportunities to modernize.

The passing on from one generation to the next is beneficial for the eastern German interviewees. This enables finding a flexible arrangement of chores and employment in a partnership, eases compatibility of family and professional life and lowers labor market risks. This discourages desisting from the ideal two-income model (employment of mothers is still valued positively), but also accepts the male breadwinner model if necessary. What seems to be an adjustment to western German conditions may also be interpreted as "typical eastern German pragmatism", as coping with adverse circumstances, which refrains from 
changing the fundamental attitude that full-time employment of mother is possible and desirable.

\section{REFERENCES}

Bernardi, Laura, Keim, Sylvia, Klärner, Andreas 2014: Social Networks, Social Influence, and Fertility in Germany: Challenges and Benefits of Applying a Parallel Mixed Methods Research Design. In Betina Hollstein \& Silvia Dominguez (eds.), MixedMethods in Studying Social Networks. Cambridge (UK): Cambridge University Press, $121-152$.

Bernardi, Laura, Keim, Sylvia, Lippe, Holger von der 2007: Social Influences on Fertility: A Comparative Mixed Methods Study in Eastern and Western Germany. Journal of Mixed Methods Research, 1(1), 23-47. DOI: 10.1177/2345678906292238.

Blau, Peter M. 1964. Exchange and power in social life. New York: Wiley.

Boehnke, Mandy. 2009. Gut gebildet = kinderlos? Zu feinen deutsch-deutschen Unterschieden im Umgang mit dem Kinderwunsch. Bios - Zeitschrift für Biographieforschung, Oral History und Lebensverlaufsanalysen 22(1): 12-31.

Brandt, Martina. 2009. Hilfe zwischen Generationen. Ein europäischer Vergleich. Wiesbaden: VS.

Diewald, Martin. 1991. Soziale Beziehungen: Verlust oder Liberalisierung? Soziale Unterstützung in informellen Netzwerken. Berlin: Ed. Sigma.

Falk, Susanne, and Hildegard Schaeper .2001. Erwerbsverläufe von ost- und westdeutschen Müttern im Vergleich. Ein Land - ein Muster? In Individualisierung und Verflechtung: 
Geschlecht und Generation im deutschen Lebenslaufregime, edited by Claudia Born, and Helga Krüger. Weinheim: Juventa.

Flick, Uwe. 2014. An introduction to qualitative research. London: SAGE.

Fthenakis, Wassilios E., Bernhard Kalicki, and Gabriele Peitz, Gabriele. 2002: Paare werden Eltern. Die Ergebnisse der LBS-Familien-Studie. Opladen: Leske \& Budrich.

Giesecke, Johannes, and Roland Verwiebe. 2010. Erwerbschancen und Arbeitsmarktintegration im wiedervereinigten Deutschland. In Leben in Ost- und Westdeutschland, edited by Peter Krause, and Ilona Ostner. Frankfurt am Main: Campus.

Granovetter, Mark S. 1985. Economic action and social structure: the problem of embeddedness. American Journal of Sociology 91(3): 481-93.

Heß, Pamela. 2010. Geschlechterkonstruktionen nach der Wende. Auf dem Weg einer gemeinsamen Politischen Kultur? Wiesbaden: VS.

Holst, Elke, and Jürgen Schupp. 2001. Employment behaviour among women in Germany. Economic Bulletin 38(11): 377-84.

Huinink, Johannes, Michaela Kreyenfeld, and Heike Trappe (eds.) 2012. Familie und Partnerschaft in Ost- und Westdeutschland. Ähnlich und doch immer noch anders. Opladen: Budrich.

Huinink, Johannes, and Dirk Konietzka, Dirk. 2003. Lebensformen und Familiengründung. Nichteheliche Elternschaft in West- und Ostdeutschland in den 1990er Jahren. In Partnerschaft und Familiengründung: Ergebnisse der dritten Welle des Familien-Survey, edited by Walter Bien, and Jan H. Marbach. Opladen: Leske \& Budrich. 
Hülser, Oliver. 1996. Frauenerwerbstätigkeit im Transformationsprozeß der deutschen Vereinigung. Ein Ost-West-Vergleich zu den Bedingungen der Erwerbstätigkeit von Frauen im geteilten und vereinigten Deutschland. Institut für Arbeitsmarkt- und Berufsforschung, Nürnberg.

Kahlert, Heike. 2007. Die Kinderfrage und der halbierte Wandel in den Geschlechterverhältnissen. In Ein Leben ohne Kinder. Kinderlosigkeit in Deutschland, edited by Dirk Konietzka, and Michaela Kreyenfeld. Wiesbaden: VS.

Kahlert, Heike. 2010. Wiedervereinigte Geschlechterverhältnisse? querelles-net, Rezensionszeitschrift für Frauen- und Geschlechterforschung 11(3), http://www.querelles-net.de/index.php/qn/article/view/894/890.

Kohli, Martin, Harald Künemund, Andreas Motel, and Marc Szydlik. 2001. Families apart?: Intergenerational transfers in East and West Germany. In The myth of generational conflict: Family and the state in ageing societies, edited by Sara Arber, and Claudine Attias-Donfut. London: Routledge.

Kohli, Martin, and Harald Künemund. 2001. Partizipation und Engagement älterer Menschen. Bestandsaufnahme und Zukunftsperspektiven. In Lebenslagen, soziale Ressourcen und gesellschaftliche Integration im Alter. Expertisen zum Dritten Altenbericht der Bundesregierung (3), edited by Deutsches Zentrum für Altersfragen. Opladen: Leske \& Budrich.

Kolinsky, Eva. 2003. Gender and the limits of equality in eastern Germany. In Reinventing gender?: Women in eastern Germany since unification, edited by Eva Kolinsky, and Hildegard M. Nickel. London: Frank Cass. 
Konietzka, Dirk, and Michaela Kreyenfeld. 2010. Familienformen und Lebensbedingungen in Ost und West. Zur sozioökonomischen Lage von Müttern in Deutschland, Frankreich und Russland. In Leben in Ost- und Westdeutschland, edited by Peter Krause, and Ilona Ostner. Frankfurt am Main: Campus.

Krause, Peter, and Ilona Ostner, eds. 2010.Leben in Ost- und Westdeutschland. Eine sozialwissenschaftliche Bilanz der deutschen Einheit 1990 - 2010. Frankfurt am Main: Campus.

Kreyenfeld, Michaela, and Esther Geisler. 2006. Müttererwerbstätigkeit in Ost- und Westdeutschland: eine Analyse mit den Mikrozensen 1991-2002. Zeitschrift für Familienforschung 18(3): 333-60.

Lauterbach, Wolfgang. 1995. Die gemeinsame Lebenszeit von Familiengenerationen. Zeitschrift für Soziologie 24(1): 22-43.

Lauterbach, Wolfgang, and Thomas Klein. 1997. Altern im Generationenzusammenhang: Die gemeinsame Lebenszeit von Eltern, Großeltern und Enkeln und Berücksichtigung des Alters bei Familiengründung. In Generationen-Beziehungen, Austausch und Tradierung, edited by Jürgen Mansel, Gabriele Rosenthal, and Andrea Tölke. Opladen: Leske \& Budrich.

Mahne, Katharina, and Andreas Motel-Klingebiel. 2010. Familiale Generationenbeziehungen. In Altern im Wandel. Befunde des Deutschen Alterssurveys (DEAS), edited by Andreas Motel-Klingebiel, Susanne Wurm, and Clemens TeschRömer. Stuttgart: Kohlhammer.

Masche, Jan G. 2000. Emotionale Unterstützung zwischen jungen Erwachsenen und ihren Eltern. Zeitschrift für Soziologie der Erziehung und Sozialisation 20(4): 362-78. 
Motel-Klingebiel, Andreas, Susanne Wurm, and Clemens Tesch-Römer, eds. 2010. Altern im Wandel. Befunde des Deutschen Alterssurveys (DEAS). Stuttgart: Kohlhammer.

Ostner, Ilona. 2006. Paradigmenwechsel in der (west)deutschen Familienpolitik. In Der demographische Wandel: Chancen für die Neuordnung der Geschlechterverhältnisse, edited by Peter A. Berger, and Heike Kahlert. Frankfurt am Main: Campus.

Pfau-Effinger, Birgit, and Birgit Geissler. 2002. Cultural change and family policies in East and West Germany. In Analysing families: Morality and rationality in policy and practice, edited by Alan Carling, Simon Duncan, and Rosalind Edwards. London, New York: Routledge.

Pfau-Effinger, Birgit, and Maike Smidt. 2011. Differences in women's employment patterns and family policies: Eastern and western Germany. Community, Work \& Family 14(2): 217-32.

Rosenfeld, Rachel A., Heike Trappe, and Janet C. Gornick. 2004. Gender and work in Germany. Before and after re-unification. Annual Review of Sociology 30: 103-24.

Rudd, Elizabeth C. 2000. Reconceptualizing gender in postsocialist transformation. Gender \& Society 14(4): 517-39.

Rüling, Anneli. 2007. Jenseits der Traditionalisierungsfallen. Wie Eltern sich Familien- und Erwerbsarbeit teilen. Frankfurt am Main: Campus.

Salles, Anne. 2006. The effects of family policy in the former GDR on nuptiality and births outside marriage. Population 61(1).

Schmitt, Christian, and Heike Trappe. 2010. Die Bedeutung von Geschlechterarrangements für Partnerschaftsdauer und Ehestabilität in Ost- und Westdeutschland. In Leben in Ost- 
und Westdeutschland, edited by Peter Krause, and Ilona Ostner. Frankfurt am Main: Campus.

Statistisches Bundesamt. 2013a. Daten zu Geburten, Kinderlosigkeit und Familien. https://www.destatis.de/DE/Publikationen/Thematisch/Bevoelkerung/HaushalteMikroze nsus/GeburtentrendsTabellenband5122203129014.pdf?_blob=publicationFile

Statistisches Bundesamt. 2013b. Kindertagesbetreuung regional 2013. https://www.destatis.de/DE/Publikationen/Thematisch/Soziales/KinderJugendhilfe/Kind ertagesbetreuungRegional5225405137004.pdf?_blob=publicationFile.

Statistisches Bundesamt. 2014. Statistiken der Kinder- und Jugendhilfe. Kinder und tätige Personen in Tageseinrichtungen und in öffentlich geförderter Kindertagespflege am 01.03.2014.

https://www.destatis.de/DE/Publikationen/Thematisch/Soziales/KinderJugendhilfe/Tage seinrichtungenKindertagespflege.html.

Szydlik, Marc. 2004. Inheritance and inequality: Theoretical reasoning and empirical evidence. European Sociological Review 20(1): 31-45.

Thelen, Tatjana. 2005. Caring grandfathers: changes in support between generations in East Germany. In Generations, kinship and care. Gendered provisions of social security in Central Eastern Europe, edited by Haldis Haukanes, and Frances Pine. Bergen: University of Bergen.

Thelen, Tatjana, and Astrid Baerwolf. 2008. Traditionalisierung in der Flexibilisierung: Familiäre Geschlechterrollen in Ostdeutschland. In Flexibilisierung. Folgen für Arbeit und Familie, edited by Marc Szydlik, Wiesbaden: VS. 
Trappe, Heike. 1995. Emanzipation oder Zwang? Frauen in der DDR zwischen Beruf, Familie und Sozialpolitik. Berlin: Akademie.

Trappe, Heike, and Annemette Sørensen. 2006. Economic relations between women and their partners: An East and West German comparison after reunification. Feminist Economics 12(4): 643-665.

Uhlendorff, Harald. 2003. Family and family orientation in East Germany. In Reinventing gender?: Women in Eastern Germany since unification, edited by Eva Kolinsky, and Hildegard M. Nickel. London: Frank Cass. Vinken, Barbara. 2001. Die deutsche Mutter. Der lange Schatten eines Mythos. München: Piper.

Wenzel, Stefanie. 2010. Konvergenz oder Divergenz? Einstellungen zur Erwerbstätigkeit von Müttern in Ost- und Westdeutschland. Gender 2(3): 59-76.

Werneck, Harald, Martina Beham, and Doris Palz, eds. 2006. Aktive Vaterschaft. Männer zwischen Familie und Beruf. Gießen: Psychosozial.

Witzel, Andreas, and Herwig Reiter. 2012: The Problem-Centred Interview. Principles and Practice. London: SAGE.

Yodanis, Carrie. 2005. Divorce Culture and Marital Gender Equality: A Cross-National Study. Gender \& Society 19(5): 644-59. 